\title{
An investigation of plasmids from Staphylococcus aureus that mediate resistance to mupirocin and tetracycline
}

\author{
Christine Needham, ${ }^{2}$ Mary Rahman, ${ }^{1}$ Keith G. H. Dyke ${ }^{2}$ and \\ William C. Noble ${ }^{1}$
}

\begin{abstract}
Author for correspondence: Keith G. H. Dyke. Tel: +44865 275293. Fax: +44865275297. e-mail: KDYKE@MOLBIOL.OX.AC.UK
\end{abstract}

1 Department of Microbial Diseases, St John's Institute of Dermatology, St Thomas' Hospital, London SE1 7EH, UK

2 Microbiology Unit, Biochemistry Department, University of Oxford, South Parks Road, Oxford OX1 3QU, UK

\begin{abstract}
Plasmids conferring mupirocin resistance were prepared from isolates of Staphylococcus aureus obtained from four patients in the same ward. The plasmids are related and in all of them the gene conferring mupirocin resistance (mupA) is flanked by copies of IS257 in direct repeat. In two plasmids mupA and IS257 have been duplicated and in one of these plasmids (pJ3358) a small pT181-like plasmid conferring tetracycline resistance is present flanked by copies of IS257. Filter mating with a strain containing pJ3358 as donor and selection on tetracycline sometimes resulted in transfer of the pT181-like plasmid containing a copy of IS257. Analysis showed that the pT181-like plasmid with the insertion of IS257 is present in high copy number and that the IS257 element is inserted in the copy number control region of the plasmid.
\end{abstract}

Keywords: Stapbylococcus aureus, plasmids, mupirocin resistance, tetracycline resistance, IS257

\section{INTRODUCTION}

Staphylococcus aureus is an important pathogen that is frequently found to be resistant to a large number of antibiotics. There is therefore a continuing search for new anti-staphylococcal antibiotics and mupirocin (Bactroban ointment from SmithKline Beecham) (Fuller et al., 1971) is such a new antibiotic that has been available for topical use since 1985 (White et al., 1985). Mupirocin has a novel action in that it inhibits the binding of isoleucine to isoleucyl tRNA synthetase, so preventing protein synthesis (Hughes \& Mellows, 1980; Mellows, 1984). Strains of $S$. aureus with a reduced sensitivity to a high concentration of mupirocin were reported in 1987 (Rahman et al., 1987; Kavi et al., 1987; Smith et al., 1987; Cookson et al., 1990; Baird \& Coia, 1987) and resistance has been found to be present in bacteria isolated as early as 1965 (Rahman et al., 1990). Despite widespread use of mupirocin, only isolated instances of resistance have been detected and the clinical significance of resistance has not been established. The mupirocin resistance $\left(\mathrm{Mu}^{\mathrm{R}}\right)$ is due to the acquisition of an isoleucyl tRNA synthetase, additional to and distinct from the chromosome-encoded enzyme, which is much less affected by mupirocin and whose gene, mupA, is plasmid-borne (Noble et al., 1988; Dyke et al., 1991; Gilbart et al., 1993; Hodgson et al.,
1994). These $\mathrm{Mu}^{\mathrm{R}}$ plasmids are variable in size and many can be transferred by filter mating (Rahman et al., 1993).

A total of 33 apparently epidemiologically independent strains of $S$. aureus and 15 strains of coagulase-negative staphylococci have yielded $41 \mathrm{Mu}^{\mathrm{R}}$ plasmids that differ on the basis of restriction enzyme digests (Rahman et al., 1993). All these plasmids hybridized with probes made from the resistance gene and, in 39 of the 41 , this hybridization was to a $4.05 \mathrm{~kb}$ EcoR 1 fragment of the plasmid (Dyke et al., 1991). Some 27 of the 48 strains carried a $\mathrm{Mu}^{\mathrm{R}}$ plasmid which was easily transferred to other staphylococci by filter mating (Rahman et al., 1993). Transconjugant colonies were checked for transfer of resistances other than $\mathrm{Mu}^{\mathrm{R}}$. In only one instance did the plasmid-bearing $\mathrm{Mu}^{\mathrm{R}}$ genes mediate any other antibiotic resistance. The ability to conjugate is specified by the plasmid since transferred plasmids have been shown to undergo a second round of transfer.

Tetracycline resistance $\left(\mathrm{Tc}^{\mathrm{R}}\right)$ is specified by a gene frequently found on small plasmids, for example pT181 (Khan \& Novick, 1983). Resistance is due to the acquisition of an efficient efflux system for tetracycline (Guay et al., 1993). However, it has been shown that a pT181-like plasmid can integrate into a large plasmid where it is flanked by copies of the staphylococcal 
Table 1. Strains used in this study

\begin{tabular}{|c|c|c|c|}
\hline Strain & $\begin{array}{l}\text { Antibiotic } \\
\text { resistance* }\end{array}$ & $\begin{array}{c}\text { Plasmids present } \\
(\mathbf{k b}) \dagger\end{array}$ & $\begin{array}{l}\text { Designation } \\
\text { of plasmid } \\
\text { in } \mathbf{M u}^{\mathrm{R}} \\
\text { transconjugant }\end{array}$ \\
\hline NCTC 8325 derivative & $\mathrm{Rf} F d$ & None & - \\
\hline NCTC 8325 (pT181) & $\mathrm{Tc}$ & $4 \cdot 4$ & - \\
\hline $\mathrm{B} 111$ & $\mathrm{Rf} F \mathrm{~d}$ & None & - \\
\hline $\mathrm{J} 3347$ & $\mathrm{Mu} \mathrm{Pc} \mathrm{Tc}$ & $34 \cdot 2,33,(5 \cdot 2), 4 \cdot 4,1 \cdot 8$ & pJ3358 \\
\hline $\mathrm{J} 3332$ & $\mathrm{Mu} \mathrm{Pc}$ & $33,29 \cdot 0,17,6 \cdot 3,++$ & pJ3357 \\
\hline $\mathrm{J} 3352$ & $\mathrm{Mu}$ Pc Tc Em & $33,23 \cdot 6,6 \cdot 3,3 \cdot 5,3 \cdot 1$ & pJ3355 \\
\hline $\mathrm{J} 3350$ & $\mathrm{Mu} \mathrm{Pc} \mathrm{Tc}$ & $33,23 \cdot 6,6 \cdot 3,4 \cdot 4,++$ & pJ3356 \\
\hline
\end{tabular}

* Abbreviations: Rf, rifampicin; Fd, fusidic acid; Tc, tetracycline; Pc, penicillin; Em, erythromycin; Mu, mupirocin.

† Parentheses around the plasmid size indicates detection only by hybridization. ++ , small plasmids present.

insertion element IS257 (Rouch \& Skurray, 1989; Gillespie et al., 1986).

This paper reports the results of detailed studies on the $\mathrm{Mu}^{\mathrm{R}}$ plasmids found in isolates from four patients in the same hospital ward. One of these plasmids transferred both $\mathrm{Mu}^{\mathrm{R}}$ and $\mathrm{Tc}^{\mathrm{R}}$.

\section{METHODS}

Bacterial strains and media. The characteristics of all strains used in this study (including the four $\mathrm{Mu}^{\mathrm{R}}$ strains isolated from the same ward) are shown in Table 1 . Strains used routinely were maintained on CY-agar or Oxoid Blood Agar Base (Unipath) for $S$. aureus and $2 \times$ TY (Sambrook et al., 1989) for Escherichia coli. Long-term storage was at $-70^{\circ} \mathrm{C}$ in broth containing $30 \%(\mathrm{v} / \mathrm{v})$ glycerol. Antibiograms were obtained as described previously (Rahman et al., 1993). Minimal inhibitory concentrations (MIC) of tetracycline were determined by incorporating tetracycline in Oxoid Blood Agar Base. Curing of plasmids was achieved by growth at $42{ }^{\circ} \mathrm{C}$ or in the presence of ethidium bromide $\left(4 \mu \mathrm{g} \mathrm{m}^{-1}\right)$.

Transfer of plasmids from wild-type to reference strains and subsequent transfer to other strains were performed by filter mating (Naidoo \& Noble, 1987).

Plasmid DNA preparation. The alkaline lysis method (Sambrook et al., 1989) was used for both small- and full-scale caesium chloride gradient preparation of plasmid DNA from $S$. aureus except that lysis was for $30 \mathrm{~min}$ at $37^{\circ} \mathrm{C}$ with lysostaphin $\left(50 \mu \mathrm{g} \mathrm{ml}^{-1}\right)$ and Stratagene Resin was used for protein precipitation.

DNA manipulations. Restriction enzymes were obtained from Gibco BRL, and used according to the manufacturer's instructions. DNA fragments were separated by electrophoresis in $0.8 \%$ or $2.0 \%(\mathrm{w} / \mathrm{v})$ agarose run in Tris/borate buffer, $\mathrm{pH} 8.0$, with appropriate size markers. DNA probes were prepared by purifying plasmid DNA using Qiagen tips (Hybaid) according to the manufacturer's instructions. A HincII fragment of $871 \mathrm{bp}$ from within the tet gene of pT181 (Khan \& Novick, 1983) was extracted from a low melting point agarose gel (Biorad) and purified using the Geneclean Kit (Stratech). Plasmids carrying fragments cloned from within the transposase genes of IS256
(pIP1551, Dyke et al., 1992) and IS257 (pIP1644, V. Loncle, personal communication) were digested with EcoRI and HindIII, and fragments of 491 and $705 \mathrm{bp}$, respectively, were purified as above. A pOX7 (identical to pOX300 in Dyke $e t$ al., 1991) clone of the $4.05 \mathrm{~kb}$ EcoRI fragment of pJ3356 was cut with EcoRI and the whole plasmid digest used as a probe (pOX7 has been shown not to hybridize to $\mathrm{p} 3356$ or $\mathrm{p} 3356 \mathrm{D}$, data not shown). Probes were labelled using the Enhanced Chemiluminescence (ECL) direct nucleic acid labelling (Amersham) or with the FLASH random priming kit (Stratagene) and purified with NucTrap push columns (Stratagene).

Southern blotting to nylon membranes was as described in Sambrook et al. (1989) and detection was carried out by the ECL or FLASH method according to the manufacturers' instructions.

DNA sequencing was performed by the method of Sanger $e t$ al. (1977) using the Sequenase kit (USB) according to manufacturer's instructions. The oligonucleotide 5' CAGTATGTGCGTCCAACC 3' was used as a sequencing primer (provided by SmithKline Beecham).

\section{RESULTS}

\section{$\mathrm{Mu}^{\mathrm{R}}$ plasmids which can undergo duplication of a segment encoding mupA}

The antibiotic resistance patterns and the plasmid profiles of four $\mathrm{Mu}^{\mathrm{R}}$ strains of $S$. aureus isolated from four patients in the same ward are shown in Table 1. In the transfer experiments, $S$. aureus 8325 or B111 were used as recipients; when selection was for $\mathrm{Mu}^{\mathrm{R}}$, a single plasmid transferred in each case. The frequencies of transfer of $\mathrm{Mu}^{\mathrm{R}}$ from J3347, J3352 and $\mathrm{J} 3350$ were about $1 \times 10^{-5}$, whereas that for $\mathrm{J} 3332$ was $1 \times 10^{-7}$. The plasmid from $\mathrm{J} 3347$ (pJ3358) was $34.2 \mathrm{~kb}$ and mediated resistance to Tc and $\mathrm{Mu}$, whilst that from J3332 (pJ3357) was $29 \mathrm{~kb}$ and those from J3352 or J3350 (pJ3355) were $23.6 \mathrm{~kb}$ and these mediated only $\mathrm{Mu}^{\mathrm{R}}$.

Plasmids pJ3358, pJ3355, pJ3357 and pJ3356 and a derivative of this last plasmid, $\mathrm{pJ} 3356 \mathrm{D}$, were mapped by 


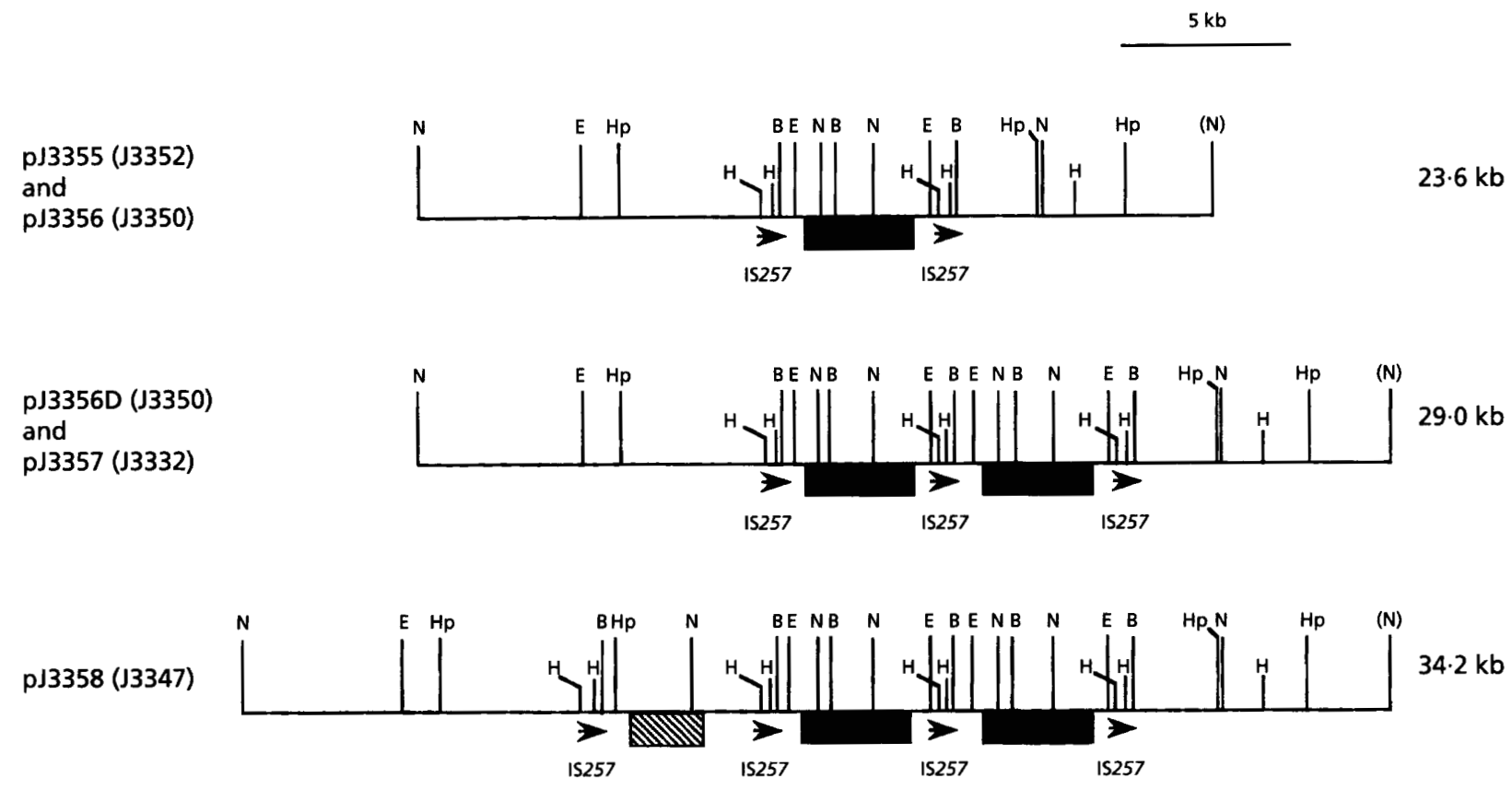

Fig. 1. Restriction enzyme maps of plasmids pJ3355, pJ3356, pJ3356D, pJ3357 and pJ3358. The black boxes represent the mupA gene, the hatched box the tet gene of the integrated pT181 plasmid. The position and orientation of the IS257 elements are shown. N, Ncol; E, EcoR1; Hp, Hpall; B, Bg/ll; H, HindIII (sites within pT181 not shown).

restriction enzyme analysis and shown to be related (Fig. 1). Strain J3350 at first was shown to contain a plasmid, pJ3356, that was indistinguishable from pJ3355 by restriction enzyme analysis (Fig. 2a). However, the transconjugant $8325(\mathrm{pJ} 3356)$ was maintained at $4{ }^{\circ} \mathrm{C}$ on $\mathrm{CY}$-agar containing $5 \mu \mathrm{g}$ mupirocin $\mathrm{ml}^{-1}$, with monthly subcultures to fresh plates (each subculture entailed a $24 \mathrm{~h}$ incubation at $37^{\circ} \mathrm{C}$. After 5 months of this practice, the plasmid contained in the strain on the plate was found to have altered; the derivative plasmid was shown to possess EcoRI, HindIII, BgIII and NcoI restriction enzyme fragments indistinguishable from those of pJ3357. The derivative plasmid pJ3356D had an extra piece of DNA compared to $\mathrm{pJ} 3356$ which appeared as a double intensity $4.05 \mathrm{~kb}$ EcoR1 band and a $1.3 \mathrm{~kb}$ EcoRI band (Fig. 2a, lane 6). Plasmid pJ3358 was very similar to pJ3356D but had additional DNA that increased the size of the second largest (6.5 kb) EcoR1 fragment to $11.7 \mathrm{~kb}$ (Fig. 1; Fig. 2, lane 8).

Restriction enzyme digests of all five plasmids were hybridized after Southern blotting to various probes. None of the plasmids hybridized to a probe consisting of the internal part of IS256. All five hybridized to a probe comprising the internal part of the transposase of IS257 (V. Loncle, personal communication), as well as to probes comprising the $4.05 \mathrm{~kb}$ EcoRI fragment containing mupA and to the $1.6 \mathrm{~kb} \mathrm{NoOI}$ or the $751 \mathrm{bp} \mathrm{XhoI-Bg/II}$ fragments derived from within the gene conferring $\mathrm{Mu}^{\mathrm{R}}$ (Rahman $e t$ al., 1993). Only plasmid pJ3358 hybridized to the probe from within the $\mathbf{T c}^{\mathbf{R}}$ gene of pT181. Fig. 2 shows an example of hybridization with IS257 and demonstrates that $\mathrm{pJ} 3357$ and $\mathrm{pJ} 3358$ both possess an additional $1.3 \mathrm{~kb}$ EcoRI fragment, as compared to $\mathrm{pJ} 3355$ and $\mathrm{pJ} 3356$, and that this fragment contains IS257 sequences. Plasmid pJ3356D also contains this $1.3 \mathrm{~kb}$ EcoRI fragment (data not shown). This additional IS257-containing sequence has been acquired by the duplication of mupA-IS257 (Fig. $1)$. This is also suggested by the replacement of the approximately $12 \mathrm{~kb} \mathrm{HpaII}$ band of pJ3356 with a band of approximately $17 \mathrm{~kb}$ in pJ3356D (Fig. 3, lanes 4 and 5), and also by the acquisition of an extra $3.8 \mathrm{~kb} \mathrm{NcoI}$ fragment (Fig. 3, lanes 3 and 6). The $12 \mathrm{~kb}, 17 \mathrm{~kb}$ and $3.8 \mathrm{~kb}$ all hybridized to the $4.05 \mathrm{~kb}$ EcoR 1 mupA clone derived from $\mathrm{pJ} 3356$. The faint $\mathrm{HpaII}$ band of $12 \mathrm{~kb}$ in the DNA prepared from pJ3356D (Fig. 3, lane 5) is thought to be a deleted form where $\mathrm{pJ} 3356 \mathrm{D}$ has reverted to a pJ3356-type plasmid in a small proportion of the population.

\section{Selection for higher resistance gives further amplification which is unstable}

As strain 8325 containing the plasmid pJ3356 with one copy of mupA had altered after long-term exposure to low concentrations of mupirocin to give the derivative pJ3356D with two copies of mupA, it was thought that the presence of the mupirocin may have selected for the duplication. It was further postulated that exposure of the strain $8325(\mathrm{pJ} 3356 \mathrm{D})$ to higher concentrations of mupirocin may select plasmids with more copies of mup in tandem. Hence, $8325(\mathrm{pJ} 3356 \mathrm{D})$ was inoculated onto a plate containing a concentration gradient of mupirocin $\left(0-10 \mathrm{mg} \mathrm{ml}^{-1}\right)$ and colonies which grew at the highest 
(a)

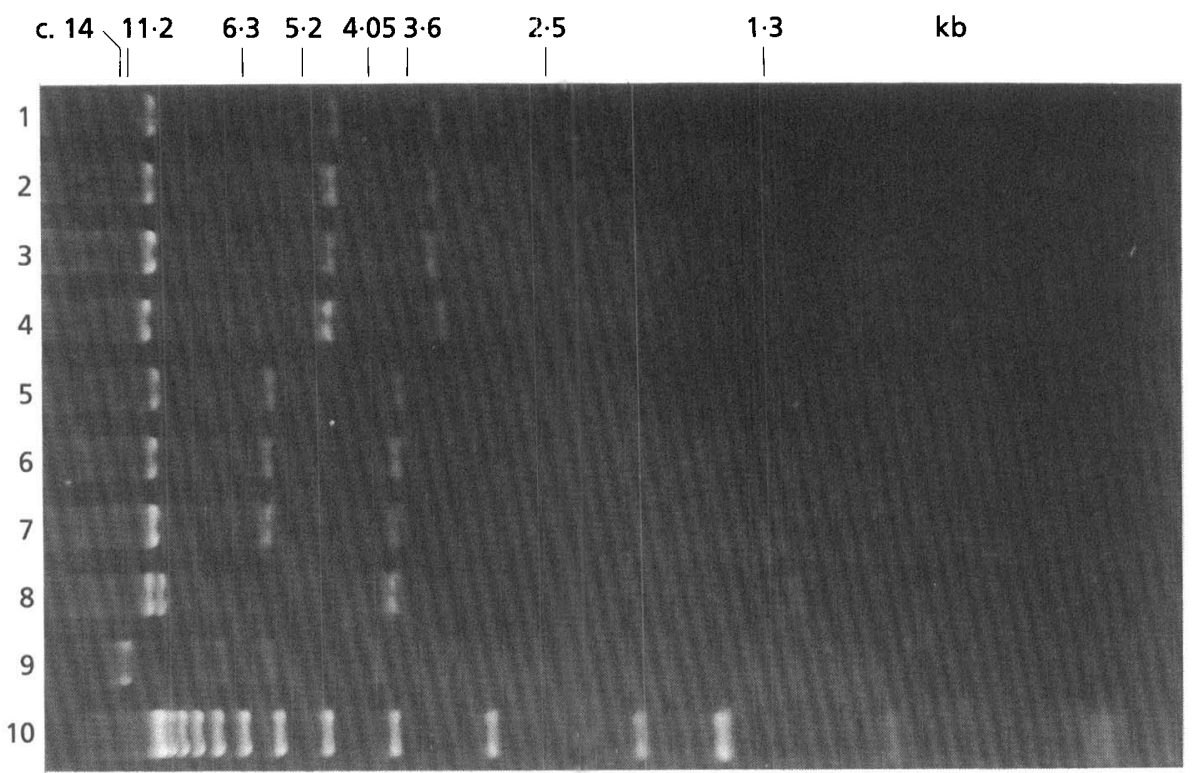

(b)

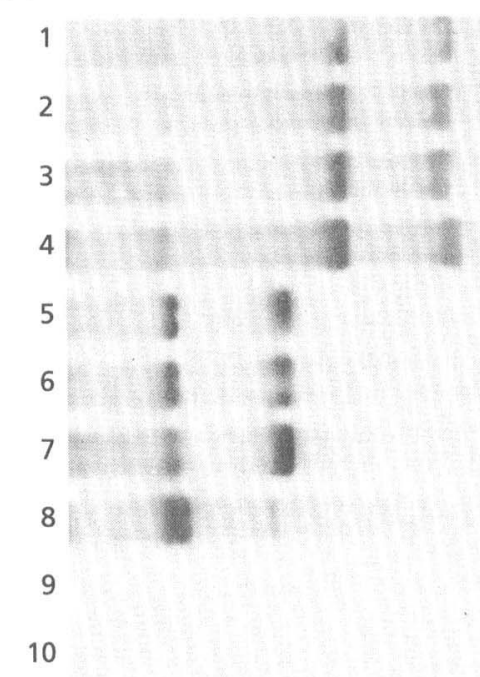

Fig. 2. (a) Digested plasmid DNA. Lanes: 1 and $5, p J 3356 ; 2$ and $6, p J 3357 ; 3$ and 7, pJ3355; 4 and 8, pJ3358; $9, \lambda D N A$ digested with EcoT141; 10, $1 \mathrm{~kb}$ ladder. DNA in lanes 1-4 was digested with HindllI and in lanes 5-8 with EcoRI. (b) Autoradiograph of the gel in (a) probed with pIP1644, which contains a fragment from within the IS257 transposase gene (see Methods).

concentrations were analysed for their plasmid content. Two types of plasmid profile were found: one which had an EcoRI restriction enzyme map identical to pJ3356D and the other which was smaller than pJ3356D and that now had a restriction map indistinguishable from that of pJ3356 with a single copy of mupA. It should be noted that although the plasmids of the pJ3356-type gave HpaII fragments of $2 \cdot 6,8.6$ and $12.4 \mathrm{~kb}$ (see Fig. 3, lane 6), the pJ3356D-type plasmid consistently gave very faint bands of approximately 23 and $28 \mathrm{~kb}$ in addition to the more intense $2 \cdot 6,8.6$ and $17.8 \mathrm{~kb}$ fragments. This suggests that a small proportion of plasmids with three or four mupA genes in tandem occur in the $\mathrm{PJ} 3356 \mathrm{D}$ population. Since this restriction enzyme profile is reproducible it is thought that the larger forms may be unstable.

\section{$\mathrm{Mu}^{\mathrm{R}}$ can be lost to give a variety of plasmids conferring $\mathrm{Tc}^{\mathrm{R}}$ only}

Filter mating studies with strain $\mathrm{J} 3347$ revealed that when selection was for transfer of $\mathrm{Mu}^{\mathrm{R}}$, all of the 871 transconjugants tested possessed both $\mathrm{Mu}^{\mathrm{R}}$ and $\mathrm{Tc}^{\mathrm{R}}$. When selection was for transfer of $\mathrm{Tc}^{\mathrm{R}}$, however, 1382 of 1391 transconjugants were both $\mathrm{Mu}^{\mathrm{R}}$ and $\mathrm{Tc}^{\mathrm{R}}$ but nine were $\mathrm{Tc}^{\mathrm{R}}$ only. All seven $\mathrm{Mu}^{\mathrm{R}} \mathrm{Tc}^{\mathrm{R}}$ transconjugants tested contained a single $34.2 \mathrm{~kb}$ plasmid, whereas the nine 

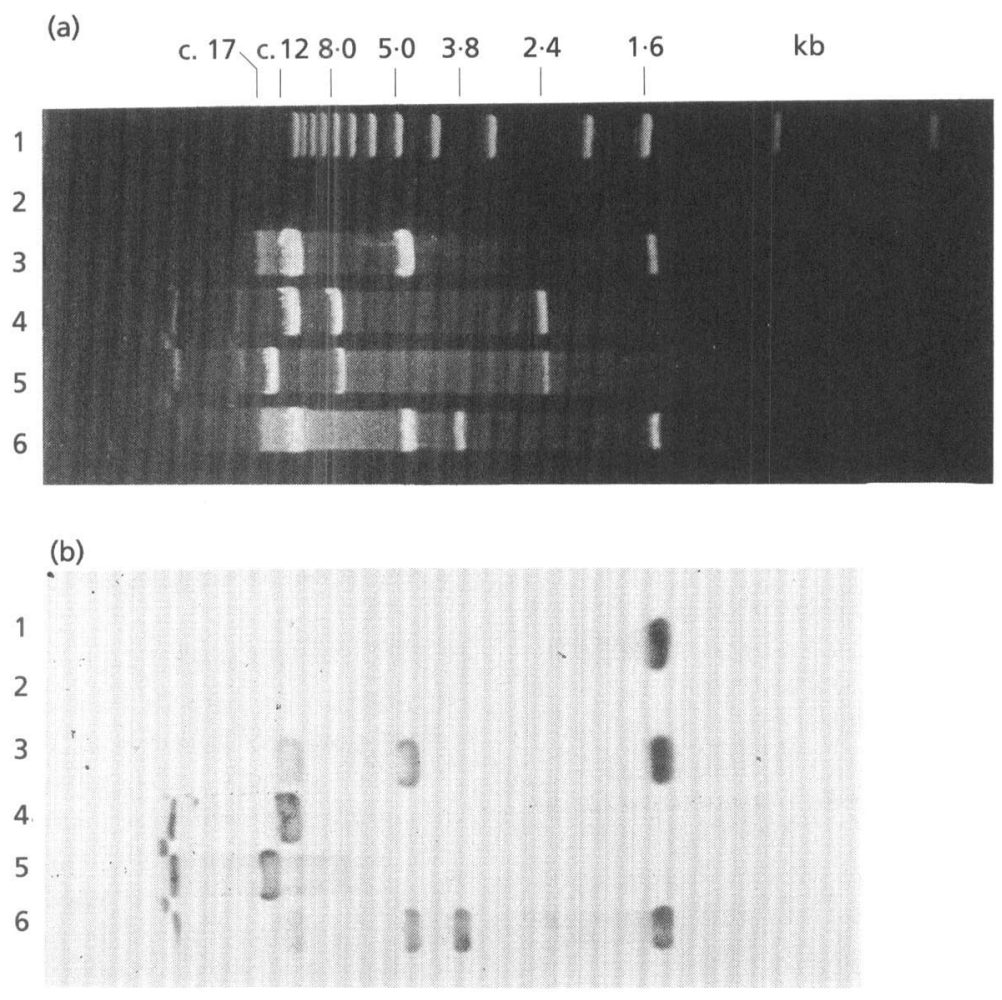

Fig. 3. (a) Digested plasmid DNA. Lanes: 1,1 kb ladder; 2, empty; 3 and 4, pJ3356; 5 and 6, pJ3356D. DNA in lanes 3 and 6 was digested with Ncol, and in lanes 4 and 5 with Hpall. (b) Autoradiograph of the gel in (a) probed with pOX7 containing the $4.05 \mathrm{~kb}$ ECORI fragment of pJ3356.

$\mathrm{Mu}^{\mathrm{S}} \mathrm{Tc}^{\mathrm{R}}$ transconjugants showed a variety of plasmid profiles. Five showed only a single plasmid of about $4.4 \mathrm{~kb}$, two had plasmids of $4.4 \mathrm{~kb}$ together with plasmids of about $20 \mathrm{~kb}$ (not mapped) and one had a $5.2 \mathrm{~kb}$ plasmid together with a plasmid of about $20 \mathrm{~kb}$ (not mapped).

To cure plasmids from strain J3347, cultures were grown in the presence of ethidium bromide and after plating colonies were obtained from which either $\mathrm{Mu}^{\mathbf{R}}$ or $\mathrm{Tc}^{\mathbf{R}}$ or both had been lost. Loss of $\mathrm{Tc}^{\mathrm{R}}$ correlated with the loss of the $4.4 \mathrm{~kb}$ plasmid together with a reduction in size of the $34.2 \mathrm{~kb}$ plasmid to $29 \mathrm{~kb}$. This latter plasmid had a restriction enzyme map indistinguishable from that of pJ3356D. Loss of $\mathrm{Mu}^{\mathbf{R}}$ was sometimes accompanied by the appearance of a $5.2 \mathrm{~kb}$ plasmid which, from the intensity of its band, was present in high copy number. Also the strain carrying it had an MIC for tetracycline of $256 \mu \mathrm{g} \mathrm{ml}^{-1}$ compared to $128 \mu \mathrm{g} \mathrm{ml}^{-1}$ of both the original J3347 strain and the transconjugants carrying the $4 \cdot 4 \mathrm{~kb}$ plasmid.

Further investigation of the plasmids by Southern blotting of plasmid DNA with the tet gene probe revealed that the gene was present on the $34.2 \mathrm{~kb}, 5.2 \mathrm{~kb}$ and $4.4 \mathrm{~kb}$ plasmids, but not on the $29 \mathrm{~kb}$ or $23.6 \mathrm{~kb}$ plasmids (data not shown). The IS 257 probe revealed the presence of IS 257 on the $5.2 \mathrm{~kb}$, but not on the $4.4 \mathrm{~kb}$ plasmid. Restriction enzyme analysis of the $5.2 \mathrm{~kb}$ plasmid that arose during selection of $\mathrm{Tc}^{\mathrm{R}}$ transfer in filter mating experiments showed that it is related to pT181 but with

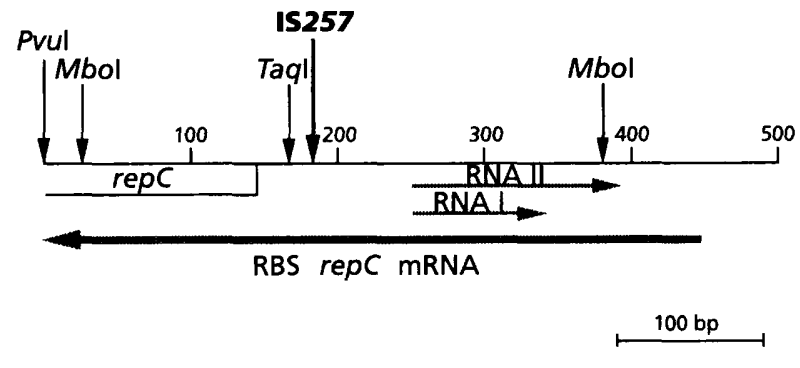

Fig. 4. Copy number control region of pT181 showing point of insertion of IS257. The numbering is in base pairs starting at the Pvul site in pT181. RNAl and RNAll are antisense RNAs.

IS 257 inserted into the $1.6 \mathrm{~kb}$ TaqI fragment and the $0.4 \mathrm{~kb} \mathrm{MboI} \mathrm{fragment} \mathrm{(Fig.} \mathrm{4).} \mathrm{The} \mathrm{precise} \mathrm{site} \mathrm{of} \mathrm{this}$ insert has been determined by sequencing the relevant part of the $5.2 \mathrm{~kb}$ plasmid (Fig. 5).

\section{DISCUSSION}

The plasmids carrying mupA in the four strains of $S$. aureus isolated within a single ward are clearly related. The plasmids of $23.6 \mathrm{~kb}$ found in J3350 and J3352 each carry a single copy of the mupA gene flanked by two copies of IS 257 in direct repeat. The $\mathrm{Mu}^{\mathrm{R}}$ plasmids of $29 \mathrm{~kb}$ derived from J3332 or J3350 contain an additional copy of the mupA gene and IS257. However, the plasmids seem to be 
unstable and can readily lose a $5.4 \mathrm{~kb}$ fragment which is the size of the duplication. The mechanism of this deletion is most likely homologous recombination between the two copies of IS257 resulting in loss of the sequence between them. This process is being investigated further. It is not clear that the presence on the plasmid of two copies of mupA increases the resistance of the strain, because even with only one copy the strain is resistant to the highest concentration of mupirocin readily obtainable in agar. The data indicate that it may be possible to convert the plasmid containing a single mupA gene to one carrying more than two copies of the mup gene each flanked by a copy of IS257 which again may be the result of homologous recombination between copies of IS257 on the two recombining plasmids.

The $34 \mathrm{~kb}$ plasmid contains a copy of a pT181-like plasmid flanked by copies of IS257. It has been shown that a deletion of this latter plasmid can occur to give rise to a plasmid of about $20 \mathrm{~kb}$ which now no longer carries $\mathrm{Tc}^{\mathrm{R}}$. Gillespie et al. (1986) reported a pT181-like plasmid integrated into the chromosome of methicillin-resistant $S$. aureus flanked by direct repeats of IS257. They did not observe deletion of the integrated pT181 but their results, together with those reported here, suggest that it is possible for $\mathrm{pT} 181$ to integrate intact into the chromosome or into a plasmid and that this process somehow involves IS257.

In some instances these interactions result in the production of a $5.2 \mathrm{~kb}$ plasmid that is a pT181-like plasmid with an integrated copy of IS257. The integrated IS257 is flanked by 8 bp direct repeats which suggests that it arrived at this site as the result of a transposition event. Presumably the insertion of the IS257 preceded the probable integration of the $5.2 \mathrm{~kb}$ plasmid into a $\mathrm{pJ} 3357$ like plasmid. Hybridization of the tet probe to the DNA of intact plasmid profiles revealed that in S. aureus $\mathrm{J} 3347$ hybridization occurred to a $5.2 \mathrm{~kb}$ plasmid not visible under UV/ethidium bromide detection suggesting that the plasmids are labile under non-selective conditions. Thus, this is another example of the involvement of IS257 in the evolution of staphylococcal plasmids.

The site in pT181 into which IS257 transposed is different from that found by Gillespie et al. (1986). In the case of the $5.2 \mathrm{~kb}$ plasmid described here, the site is between the start of the translation of the RepC messenger RNA and the promoter for RNAs I and II that are believed to be involved in copy number control of pT181. It is therefore of interest to note that the copy number of plasmid DNA is very much higher for the $5 \cdot 2 \mathrm{~kb}$ plasmid than for $\mathrm{pT} 181$ itself in the same host as judged by the intensity of staining. This is supported by the higher MIC of tetracycline in the former. In its location in the $5.2 \mathrm{~kb}$ plasmid, the IS257 would be expected to interrupt synthesis of the $\operatorname{rep} C \mathrm{mRNA}$ since it is between the promoter and the translational start site (Fig. 4). If this assumption is correct, then it is assumed that the IS257 itself provides promoter sequences at least in part to allow the synthesis of RepC. Whatever the promoter sequences used, it is of note that the IS257 has integrated into the stem-loop structure predicted to be involved in the

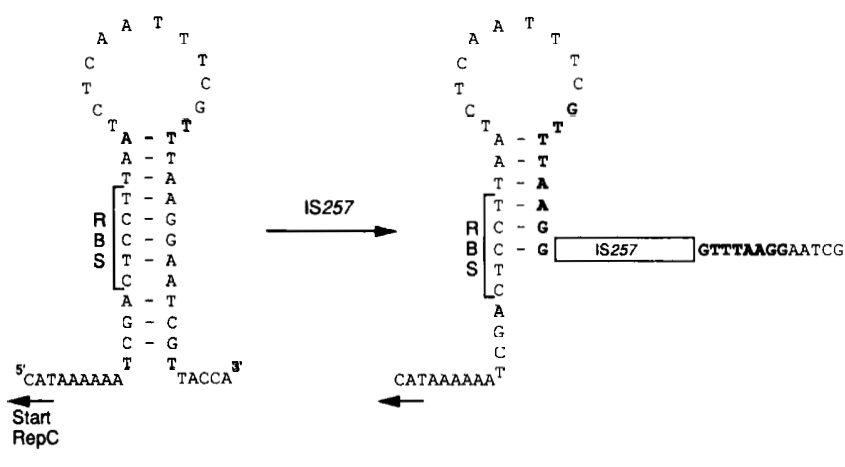

Fig. 5. Sequence of the copy number control region of pT181 showing the point of insertion of IS257 into pT181. The $8 \mathrm{bp}$ direct repeat flanking IS257 is shown in bold.

attenuation of the repC transcript (Projan et al., 1990). This may go some way to explaining the high copy number of the $5.2 \mathrm{~kb}$ plasmid as compared with the $4.4 \mathrm{~kb}$ plasmid, since the insertion into the proposed stem will render the attenuation structure much weaker and therefore the level of attenuation would be reduced in the larger plasmid. In Fig. 5 the stem-loop is shown as that formed by a single strand of DNA since it is not clear whether this structure will be present as RNA when IS257 is present.

\section{ACKNOWLEDGEMENTS}

C. $N$. is the recipient of an SERC-Case Award in conjunction with SmithKline Beecham.

\section{REFERENCES}

Baird, D. \& Coia, J. (1987). Mupirocin resistant Staphylococcus aureus. Lancet II, 387-388.

Cookson, B. D., Lacey, R. W., Noble, W. C., Reeves, D. S., Wise, R. \& Redhead, R. J. (1990). Mupirocin resistant Stapbylococcus aureus. Lancet II, 1095-1096.

Dyke, K. G. H., Curnock, S. P., Golding, M. \& Noble, W. C. (1991). Cloning of the gene conferring resistance to mupirocin in Staphylococcus aureus. FEMS Microbiol Lett 77, 195-198.

Dyke, K. G. H., Aubert, S. \& El Solh, N. (1992). Multiple copies of IS256 in staphylococci. Plasmid 28, 235-246.

Evans, J. \& Dyke, K. G. H. (1988). Characterisation of the conjugation system associated with the Stapbylococcus aureus plasmid pJE1. J Gen Microbiol 134, 1-8.

Fuller, A. T., Mellows, G., Woolford, M., Banks, G. T., Barrow, K. D. \& Chain, E. B. (1971). Pseudomonic acid: an antibiotic produced by Pseudomonas fluorescens. Nature 234, 416-417.

Gilbart, J., Perry, C. R. \& Slocombe, B. (1993). High level mupirocin resistance among Stapbylococcus aureus: evidence of two distinct isoleucine-tRNA-synthetases. Antimicrob Agents Chemother 37, 3238.

Gillespie, M. T., May, J. W. \& Skurray, R. A. (1986). Detection of an integrated tetracycline resistance plasmid in the chromosome of methicillin-resistant Stapbylococcus aureus. J Gen Microbiol 132 , 1723-1728.

Gillespie, M. T., Lyon, B. R., Loo, L. S. L., Matthews, P. R., Stewart, P. R. \& Skurray, R. A. (1987). Homologous direct sequences 
associated with mercury, methicillin, tetracycline and trimethoprim resistant determinants on Staphylococcus aureus. FEMS Microbiol Lett 43, 165-171.

Guay, G. G., Khan, S. A. \& Rothstein, D. M. (1993). The tet(K) gene of plasmid pT181 of Stapbylococcus aureus encodes an efflux protein that contains 14 transmembrane helices. Plasmid 30, 163-166.

Hodgson, J. E., Curnock, S. P., Dyke, K. G. H., Morris, R., Sylvester, D. R. \& Gross, M. S. (1994). Molecular characterisation of the gene encoding high-level mupirocin resistance in Stapbylococcus aureus, J2870. Antimicrob Agents Chemother 38, 1205-1208.

Hughes, J. \& Mellows, G. (1980). Interaction of pseudomonic acid A with Eschericbia coli B isoleucyl tRNA synthetase. Biochem J 191, 209-219.

Kavi, J., Andrew, J. M. \& Wise, R. (1987). Mupirocin resistant Staphylococcus aureus. Lancet II, 1472.

Khan, S. A. \& Novick, R. P. (1983). Complete nucleotide sequence of pT181, a tetracycline-resistance plasmid from Stapbylococcus aureus. Plasmid 10, 251-259.

Mellows, G. (1984). The mode of action of mupirocin. In London Royal Society of Medicine, Mupirocin, a Novel Topical Antibiotic. International Congress and Symposium Series No. 80, pp. 23-29. Edited by D. S. Wilkinson and J. D. Price. London: Royal Society of Medicine.

Naidoo, J. \& Noble, W. C. (1987). Skin as a source of transferable antibiotic resistance in coagulase-negative staphylococci. Zentrabl Bakteriol Mikrobiol Hyg Suppl 16, 225-234.

Noble, W. C., Rahman, M. \& Cookson, B. (1988). Transferable mupirocin resistance. J Antimicrob Chemother 22, 771.

Projan, S. J., lordanescu, S., Kornblum, J., Edelman, I. \& Novick, R. P. (1990). Regulation of pT181 plasmid replication is by an antisense RNA-mediated attenuation mechanism. In Molecular Biology of the Stapbylococci, pp. 301-307. Edited by R. P. Novick. New York: VCH Publishers.

Rahman, M., Noble, W. C. \& Cookson, B. (1987). Mupirocin resistant Staphylococcus aureus. Lancet II, 387.

Rahman, M., Connolly, S., Noble, W. C., Cookson, B. \& Phillips, I. (1990). Diversity of staphylococci exhibiting high-level resistance to mupirocin. J Med Microbiol 33, 97-100.

Rahman, M., Noble, W. C. \& Dyke, K. G. H. (1993). Probes for the study of mupirocin resistance in staphylococci. J Med Microbiol 39, 446-449.

Rouch, A. \& Skurray, R. A. (1989). IS257 from Stapbylococcus aureus: a member of an insertion sequence superfamily prevalent among Gram-positive and Gram-negative bacteria. Gene 76, 192-205.

Sambrook, J., Fritsch, E. F. \& Maniatis, T. (1989). Molecular Cloning: A Laboratory Manual, 2nd edn. Cold Spring Harbor, New York: Cold Spring Harbor Laboratory.

Sanger, F., Nicklen, S. \& Coulson, A. R. (1977). DNA sequencing with chain termination inhibitors. Proc Natl Acad Sci USA 74, 5463-5467.

Smith, M. D., Sunghrajka, M. \& Lak, S. (1987). Mupirocin resistant Stapbylococcus aureus. Lancet II, 1472-1473.

White, A. R., Beale, A. S., Boon, R. J., Griffin, K. E., Masters, P. J. \& Sutherland, R. (1985). Antibacterial activity of mupirocin. In Bactroban (mupirocin) Proceedings of an International Symposium (Current Clinical Practice Series 16), pp. 19-36. Edited by R. L. Dobson, J. J. Leyden, W. C. Noble \& J. D. Price. Amsterdam: Excerpta Medica.

Received 25 January 1994; revised 5 May 1994; accepted 8 June 1994. 